\title{
PREVALENCE OF ACADEMIC CHEATING IN THE UNIVERSITY DURING THE COVID-19 PANDEMIC-CAUSED SHIFT TOWARDS ONLINE LEARNING
}

Jarmila HONZÍKOVÁ* , Západočeská univerzita v Plzni, Česká republika

Daniel AICHINGER, Západočeská univerzita v Plzni, Česká republika

Jan KROTKÝ, Západočeská univerzita v Plzni, Česká republika

Ján BAJTOŠ, Vysoká škola DTI, Slovenská republika

Přijato: 27. 4. 2021 / Akceptováno: 15. 9. 2021

Typ článku: Teoretická studie

DOI: 10.5507/jtie.2021.014

\begin{abstract}
Restrictions applied by the government in order to curb the spread of the COVID-19 virus claimed a forced transfer to distance learning in a wide range of school levels, including universities preparing future teachers. The research is focused on school cheating during online testing of future teachers - students of Teacher Training for Kindergartens and Teacher Training for Primary Schools. The questionnaire survey examined a relatively narrow range of possibilities how to cheat - the use of the socalled crib or cheat sheet, also in its electronic form. The aim of the research was to compare the possibilities and approaches to cheating by students during in-class and online examination. Although these are future educators, supposedly having higher moral credit, cheating has occurred and continues to occur even now. A sample of 121 respondents did not confirm a higher rate of use of a prohibited devices in written tests, as expected, but only in online oral exams. The results of the survey within the above mentioned groups of respondents nevertheless seem to have been confirmed to some extent by similar researches, eg. Reedy et al., 2021 or Chirumamilla et al. 2020.
\end{abstract}

Key words: cheating, online teaching, testing, college, university, teacher training, cheating prevention, COVID-19, academic integrity, code of ethics. 


\title{
MOŽNOSTI PODVÁDĚNÍ V ONLINE VÝUCE NA VYSOKÉ ŠKOLE V OBDOBÍ PANDEMIE COVID-19
}

\begin{abstract}
Abstrakt: Vládní omezení aplikovaná s cílem omezit šíření viru způsobující nemoc COVID-19 si vyžádala nucený přechod na distanční výuku v širokém spektru stupňů škol. Vysoké školy připravující budoucí pedagogy nevyjímaje. Výzkum je zaměřen na školní podvádění při online ověřování znalostí u budoucích pedagogů - studentů Učitelství pro mateřské školy a Učitelství pro 1. stupeň základních škol. Dotazníkovým šetřením bylo zkoumáno relativně úzké spektrum možností podvádění - využití tzv. taháku, a to i v jeho elektronické formě. Cílem výzkumu bylo porovnat možnosti a přistupy k podvádění u studentů při prezenčním a online zkoušení. Ačkoliv se jedná o skupiny budoucích pedagogů, tedy o lidi s předpokladem vyššího morálního kreditu, k podvádění docházelo a dochází i ted'. Vzorek 121 respondentů nepotvrdil vyšší míru využívání zakázaného prostředku při písemných testech, jak bylo původně předpokládáno. Nárůst je ovšem navzdory očekáváním zřetelný v případě online ústního zkoušení. Výsledky šetření v rámci uvedených skupin respondentů potvrzují do jisté míry obdobné výzkumy např. Reedy a kol., 2021 nebo Chirumamilla a kol. 2020.
\end{abstract}

Klíčová slova: podvádění, online výuka, testování, vysoká škola, příprava učitelů, prevence podvádění, COVID-19, morální kodex.

*Autor pro korespondenci: jhonziko@kmt.zcu.cz

\section{1 Úvod}

Současná pandemická situace převedla veškerou výuku na vysokých školách do distanční podoby. Distanční vzdělávání procházelo od svého počátku vzniku určitým vývojem, ale jeho smysl je stále stejný - výuka bez fyzického kontaktu studenta a vyučujícího. $\mathrm{V}$ počátcích probíhalo distanční vzdělávání korespondenční formou, kdy byly tištěné materiály zasílány studentovi poštou. Později byly výukové materiály distribuovány jako nahrávky na audiokazetách, později na videokazetách. Ke změně distribuce výukových materiálů došlo s př́chodem rádia, televize a satelitů, tehdy již byly vysílány mediálně zpracované výukové materiály. Ovšem zvrat $\mathrm{v}$ distribuci přišel s osobními počítači, kdy mohly být distribuovány jako výukové materiály i videa a student si je mohl přehrávat dle potřeby. Dnes má distanční vzdělávání zcela novou podobu za podpory digitálních technologií a sítové komunikace, kdy je učitel v kontaktu se studentem právě přes dálkový přenos on-line, či může využít různé mediální platformy pro zadávání a plnění 
úkolů. Ovšem využívání osobních počítačů a dalších digitálních technologií přìnáší i svoje negativa, mezi něž můžeme zařadit i nové formy školního podvádění.

\section{Teoretická východiska výzkumu}

Definováním pojmu podvádění, resp. školní podvádění, se ve svých pracích zabývá mnoho autorů, nebơ je to jev, který je na všech stupních vzdělávání nežádoucí. Cizek (2003), Simkin a McLeod (2010) ve svých statích dokazují, že podvádění je dopředu promyšlené, záměrné a úmyslné konání jedince, jiní autoři (např. Haines et al. 1996) označují podvádění za epidemický jev. Vzájemné propojení podvádění na jednotlivých stupních vzdělávání dokladuje Gray (2013). Důvody, proč studenti a žáci podvádějí, se ve svých statích zabývaly autorky Norman a Harris (1981). Jejich výzkumy uvádějí, že hlavní prríčinnou školního podvádění je tlak, který je vyvíjen na žáky tak, aby měli dobré známky. Další oblastí zkoumání tohoto nežádoucího jevu jsou techniky podvádění, které se podle některých autorů značně liší podle stupně vzdělávání, tzn. jiné techniky používají žáci základních škol, jiné studenti středních a vysokých škol (Garavalia et al. 2007). Metodami školního podvádění se ve svých pracích zabývalo více autorů, např. Kumar (2002), Eisenberg (2004), či Bernardi et al. (2008). V České republice se problematikou školního podvádění zabýval Mareš (2005), který rozdělil školní podvádění na dvě základní skupiny - tradiční a elektronické.

Konkrétními typy školního podvádění u českých žáků zkoumala Vrbová (2012), která se zabývala nejen typy školního podvádění, ale i otázkou, zda je podvádění asociované s některou z vybraných charakteristik žáka (pohlaví, prospěch, školní absence). Na Slovensku provedli výzkum o podvádění na základních školách Bajtoš a Marhevková (2016, 2019), kteří se soustředili na školní podvádění v souvislostí s hodnocením žákovských výkonů. Rozsáhlý mezinárodní výzkum školního podvádění na středních školách realizoval tým pod vedením profesora Jána Bajtoše (Honzíková, Simbartl, Bajtoš, 2020). Tento výzkum odhalil nejen motivy školního podvádění u středoškolských studentů v Česku, na Slovensku a v Polsku, ale také dospěl k závěru, že s nástupem nových digitálních technologií se mění i formy a způsoby podvádění na stř̌ední škole.

V době distanční výuky se ve větší míře vyskytuje také plagiátorství, které lze považovat taktéž za formu podvádění. Pod pojmem plagiátorství rozumíme neetické chování, jehož základním znakem je „vydávání cizího literárního či jiného uměleckého či vědeckého díla za svoje vlastní, popřípadě převzetí části cizí práce, bez 
uvedení použitých zdrojü“ (Havlová, 2003). Někdy se ovšem setkáváme, především na vysoké škole, $s$ tzv. neúmyslným plagiátem, kdy student zapomene uvést citaci či zdroj informace (Bajtoš, Honzíková, 2019; Bajtoš, Honzíková, Bajtoš, 2020).

Jeden $\mathrm{z}$ nejnovějších výzkumů zaměřených na školní podvádění byl realizován v Austrálii v roce 2020 v rámci tř́ místních univerzit a vyhodnocoval př́stupy studentů k podvádění již za doby ovlivněné pandemií COVID-19. Tým kolem Alison Reedy ve svém výzkumu zjistil několik specifických faktů charakteristických právě pro distanční ověřování znalostí. V př́ípadě distančního zkoušení nemusí všichni studenti pochopit, které zdroje informací jsou povoleny a které ne, pokud ty nejsou jednoznačně definované. Např. si studenti mohou myslet, že pokud používají během online zkoušení počítač, tak všechny prostředky jím dosažitelné jsou při ověřování povolené. Podobně ve zvýšené míře dochází k nežádoucí paralelní komunikaci mezi studenty, a to i s využitím dalších prostředků, např. mobilních telefonů. Dalším specifikem podle autorů je i „předstírání jiné identity“" (Reedy a kol., 2021).

\section{Cíle dotazníkového šetření}

Cílem realizovaného dotazníkového šetření bylo zjistit nejen hlavní nástroje podvádění, ale také motivy podvádění a postoje studentů ke školnímu podvádění. $\mathrm{V}$ této výzkumné studii se zaměříme pouze na část výzkumu, jejímž cílem bylo zjistit,

- zda studenti Fakulty pedagogické Západočeské univerzity v Plzni, konkrétně magisterského studijního oboru Učitelství pro 1. stupeň ZŠ a bakalářského studijního oboru Učitelství pro mateřské školy používají při školním podvádění více digitální technologie, jako jsou napřs smartphone (chytrý telefon) a smartwatch (chytré hodinky) nebo papírové taháky,

- zda studenti Fakulty pedagogické Západočeské univerzity v Plzni, konkrétně magisterského studijního oboru Učitelství pro 1. stupeň ZŠ a bakalářského studijního oboru Učitelství pro mateřské školy podváděli více v době prezenční výuky nebo v době distanční výuky.

V naší výzkumné studii se zaměříme na prezentaci výsledků k ověřování dvou hypotéz:

$\mathbf{H}_{1}$ - Studenti Učitelství pro MŠ při písemných testech v době distanční výuky podvádějí více, než tomu bylo v době prezenční výuky. 
$\mathbf{H}_{2}$ - Studenti Učitelství pro 1. stupeň ZŠ při písemných testech v době distanční výuky podvádějí více, než tomu bylo v době prezenční výuky.

\section{Použité metody}

Primární metodou výzkumu bylo dotazníkové šetření. Dotazník byl rozeslán 450 studentům bakalářského studijního programu Učitelství pro mateřské školy, magisterského programu Učitelství pro 1. stupeň základní školy a studentům oboru Technická výchova v bakalářském i navazujícím magisterském studiu Fakulty pedagogické Západočeské univerzity v Plzni. Dotazník vyplnilo 50 respondentů Z oboru studia Učitelství pro 1 . st ZŠ, 71 respondentů z oboru studia Učitelství pro mateřské školy a 24 respondentů oboru Technická výchova, celkově tedy pouze $31 \%$ oslovených studentů bylo ochotno dotazník vyplnit. Pro účely této výzkumné studie jsme se zaměřili pouze na respondenty Učitelství pro MŠ a Učitelství pro 1. st. ZŠ.

Výzkumné metody

- metoda analýzy a syntézy poznatků z literatury zaměřené na školní podvádění, analýza poznatků $\mathrm{z}$ dostupných zdrojů

- dotazníková metoda

- matematicko-statistické metody na vyhodnocení výsledků výzkumného šetření

\section{Průběh a výsledky výzkumu}

Cílem výzkumu bylo zjistit, zda se on-line výuka podílí na zvýšení četnosti opisování při zkušebních testech a při on-line zkoušení na vysoké škole, konkrétně u studentů Učitelství pro MŠ a Učitelství pro 1. st. ZŠ. Zajímalo nás také, zda když už se tohoto nečestného jednání dopustí, používají k tomu více papírové taháky nebo dostupné digitální technologie. Obdobný výzkum proběhl na středních školách v Česku, v Polsku a na Slovensku, ovšem pouze v době prezenční výuky. Dotazníkovým šetřením bylo zjištěno, že studenti středních škol při svém podváděním za účelem získání lepších výsledků při studiu použivají ponejvíce psané či jinak připravené papírové taháky. 57,6\% studentů přiznalo, že takový tahák používají téměř vždy, často nebo občas. Mobilní telefon jako nástroj školního podvádění používá téměř vždy, často nebo občas pouze $44,4 \%$ studentů. A ještě méně studentů používá téměř vždy, často nebo občas inteligentní hodinky, jedná 
se pouze o 16,1 \% dotazovaných studentů z České republiky, Slovenska a Polska. K podobným výsledkům došli i ostatní autoři (Mareš, 2005, Vrbová, 2013; Garavalia et al., 2007). Nás zajímalo, zda studenti vysoké školy používají při nečestném jednání více papírové taháky či mobilní telefony a jak se toto nečestné jednání změnilo v době distanční výuky.

\section{Výsledky dotazníkového šetření}

Pro dotazníkové šetření byl sestaven vícepoložkový anonymní dotazník. Dotazník byl distribuován přes Google formulář v prvních dvou měsících letního semestru akademického roku 2020/2021. Pro účely této výzkumné studie jsme se zaměřili pouze na odpovědi, které by potvrdily či vyvrátily stanovené hypotézy.

Hlavní otázkou celého výzkumného šetření bylo, zda se zvýšilo studentské podvádění v době distanční výuky a zda k tomu volí spíše papírové taháky nebo IKT, jako jsou např. mobilní telefony či smartwatch (inteligentní hodinky).

Výsledky z výzkumného šetření budeme pro větší prehlednost prezentovat v pořadí: otázka - graf vždy pro jednotlivé studijní programy.

Otázka č.1:

\section{Jak často jste používali při písemném testu papírový tahák?}

Respondenti - studijní program Učitelství pro mateřské školy (MŠ)
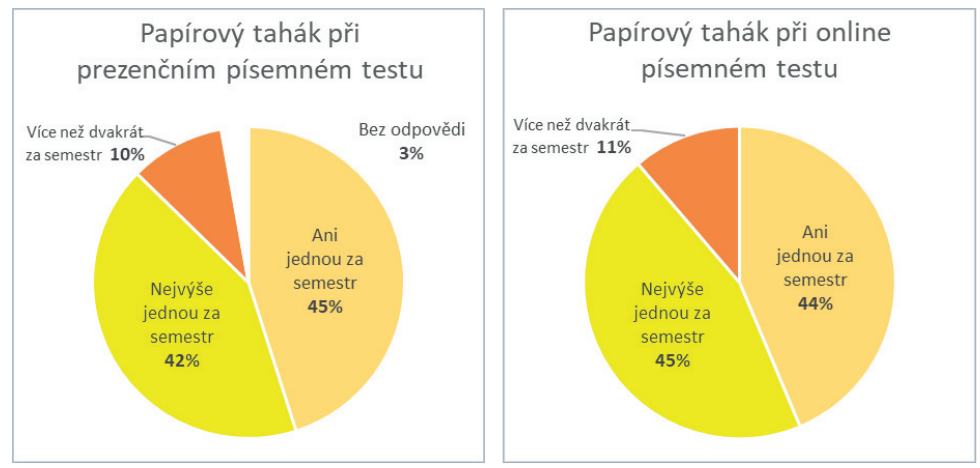

Obr. č. 1: Grafy porovnávající využívání papírového taháku v době prezenční výuky (vlevo) a v době distanční výuky (vpravo) u studujíích Učitelství pro MŠ na FPE ZČU. 
Respondenti - studijní program Učitelství pro 1. stupeň základní školy (ZŠ)
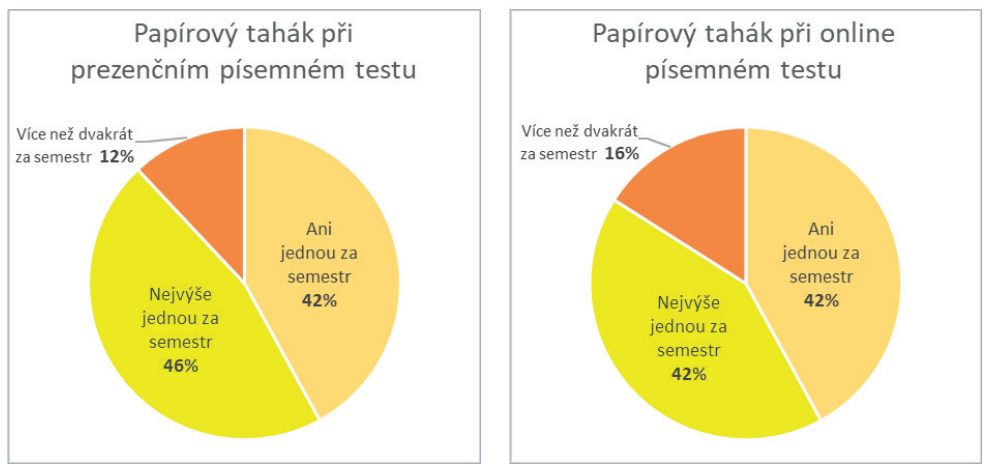

Obr. č. 2: Grafy porovnávající využivání papírového taháku v době prezenční výuky (vlevo) a v době distanční výuky (vpravo) u studujicích Učitelství pro 1.st. ZŠ na FPE ZČU.

\section{Otázka č.2:}

\section{Jak často jste použivali při písemných testech taháky na displeji mobilu nebo počítače?}

Respondenti - studijní program Učitelství pro MŠ
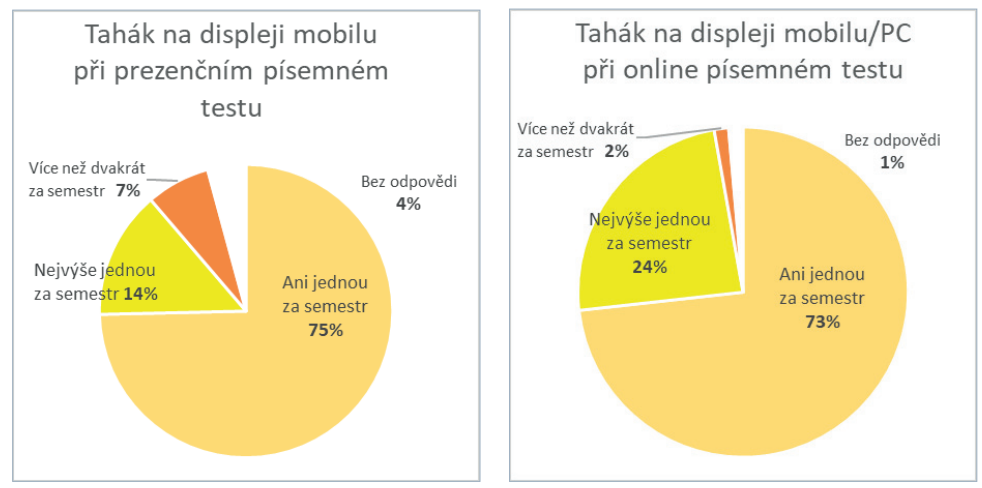

Obr. č. 3: Grafy porovnávající využivání taháku na displeji v době prezenční výuky (vlevo) a v době distanční výuky (vpravo) u studujících Učitelství pro MŠ na FPE ZČU. 
Respondenti - studijní program Učitelství pro 1. stupeň ZŠ
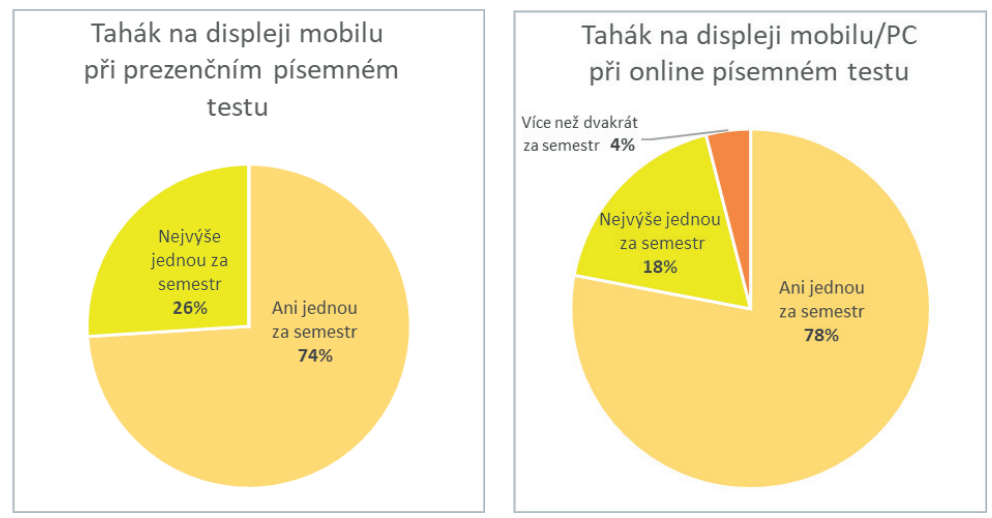

Obr. č. 4: Grafy porovnávající využívání taháku na displeji v době prezenční výuky (vlevo) a v době distanční výuky (vpravo) u studujících Učitelství pro 1. st. ZŠ na FPE ZČU.

Z výsledků dotazníkového šetření vyplývá, že více než polovina, přesněji zhruba 55 až $58 \%$, studujících Učitelství pro mateřské školy a Učitelství pro 1. stupeň základní školy používá při zápočtových testech konzistentně taháky v papírové podobě, a to bez ohledu na změnu formy výuky a testování z prezenční na online formu. Oproti tomu elektronické taháky na displejích mobilních telefonů a chytrých hodinek použila při zápočtovém testu alespoň jednou shodně pouze zhruba jedna čtvrtina, tedy 22 až $27 \%$, studujících těchto oborů. Rozdíly v řádu jednotek \% mezi oběma obory, stejně jako rozdíly mezi distanční a online výukou se z výsledků jeví být i zde spíše fluktuací v rámci statistické nejistoty než jednoznačným trendem.

\section{Shrnutí výsledků}

V této výzkumné studii byly prezentovány pouze výsledky vztahující se k ověření dvou hypotéz:

$H_{1}$ - Studenti Učitelství pro MŠ při písemných testech v době distanční výuky podvádějí více, než tomu bylo $v$ době prezenční výuky.

$\mathrm{H}_{2}$ - Studenti Učitelství pro 1. stupeň ZŠ při písemných testech $\mathbf{v}$ době distanční výuky podvádějí více, než tomu bylo v době prezenční výuky. 
Tab. č. 1 a 2: Shrnutí - využívání papírového taháku při písemném testu

\begin{tabular}{|c|c|c|c|c|}
\hline \multirow{3}{*}{ MS̆ } & \multicolumn{4}{|l|}{ Pisemný test } \\
\hline & \multicolumn{2}{|c|}{ Papirový tahák u pisemného testu } & \multicolumn{2}{|c|}{ Tahák na mobilu/počitači u pisemného testu } \\
\hline & Prezenčni & Online & Prezenčni & Online \\
\hline \multirow{4}{*}{$\begin{array}{l}\text { Nikdy } \\
\text { Nanejvýš jednou za semestr } \\
\text { Vice než dvakrát za semestr } \\
\text { bez odpovědi }\end{array}$} & 32 & 31 & 53 & 52 \\
\hline & 30 & 32 & 10 & 17 \\
\hline & 7 & 8 & 5 & 1 \\
\hline & 2 & 0 & 3 & 1 \\
\hline kontrolni suma & 71 & 71 & 71 & 71 \\
\hline
\end{tabular}

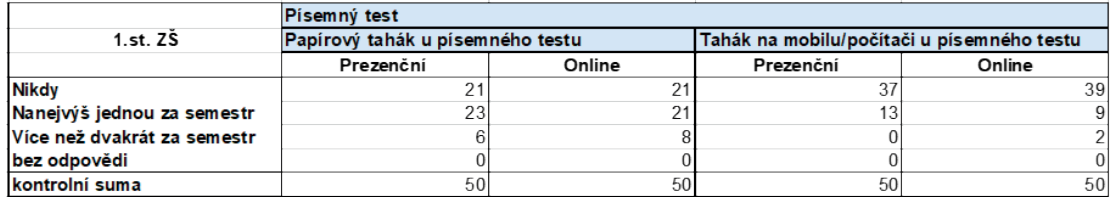

Hypotézy $\mathrm{H}_{1}$ a $\mathrm{H}_{2}$ se nepotvrdily, nebot na základě získaných dat nelze $\mathrm{s}$ jistotou konstatovat, že by studenti Učitelství MŠ a studenti Učitelství pro 1. st. ZŠ při písemném testu podváděli více při distanční výuce než při prezenční výuce.

Zatímco $\mathrm{v}$ př́ípadě písemných testů tedy nebyly zjištěny významnější rozdíly mezi prezenční a online výukou, $\mathrm{v}$ př́ípadě ústního online zkoušení již byl zjištěný nárůst používání předem vypracovaných písemných podkladů a papírových taháků z $12 \%$ na $24 \%$ v př́padě studujících učitelství 1 . stupně a ze $17 \%$ na $31 \%$ u studujících učitelství pro mateřské školy již významný. Navíc studující v případě online výuky častěji uváděli, že tyto metody použili více než dvakrát za semestr.

Tab. č. 3: Shrnutí - využívání papírového taháku príi ústním zkoušení - Uč. pro MŠ

\begin{tabular}{|c|c|c|c|c|}
\hline \multirow{3}{*}{ MS } & \multicolumn{4}{|l|}{ Û́stni zkoušení } \\
\hline & \multicolumn{2}{|c|}{ Papirovy tahák u ústni zkoušky } & \multicolumn{2}{|c|}{ Připrava v mobilu'počitači u ústni zkoušky } \\
\hline & Prezenční & Online & Prezenční & Online \\
\hline Nikdy & 59 & 49 & 64 & 59 \\
\hline Nanejýś jednou za semestr & 7 & 19 & 4 & 11 \\
\hline Vice než dvakrát za semestr & 1 & 2 & 0 & 0 \\
\hline bez odpovědi & 4 & 1 & 3 & 1 \\
\hline kontrolní suma & 71 & 71 & 71 & 71 \\
\hline
\end{tabular}

Tab. č. 4: Shrnutí - využivání papírového taháku prì ústním zkoušení - 1. st. Zక̌

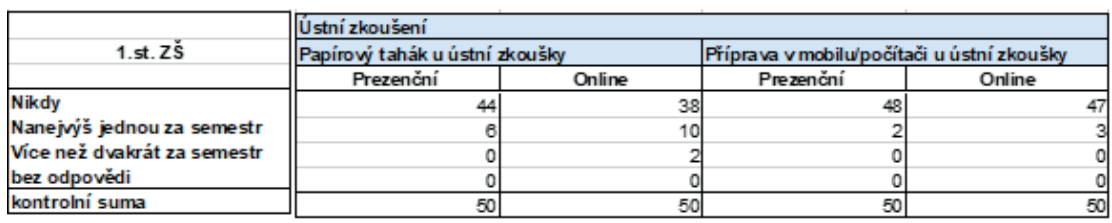


Otázka č. 3:

\section{Jak často jste používali u zkoušek papírový tahák?}

Respondenti - studijní program Učitelství pro MŠ
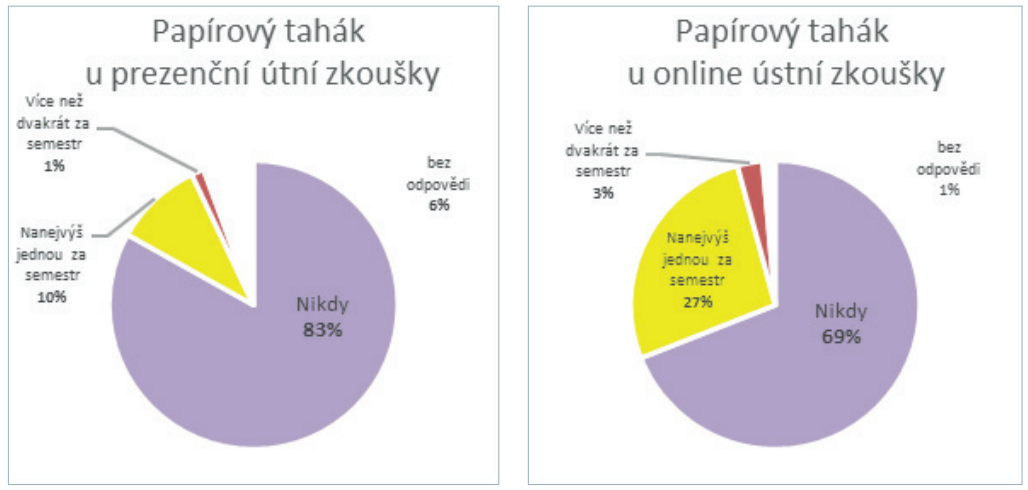

Obr. č. 5: Grafy porovnávající využívání taháků na displeji v době prezenční výuky (vlevo) a v době distanční výuky (vpravo) u studujíích Učitelství pro MŠ na FPE ZČU.

Respondenti - studijní program Učitelství pro 1. stupeň ZŠ
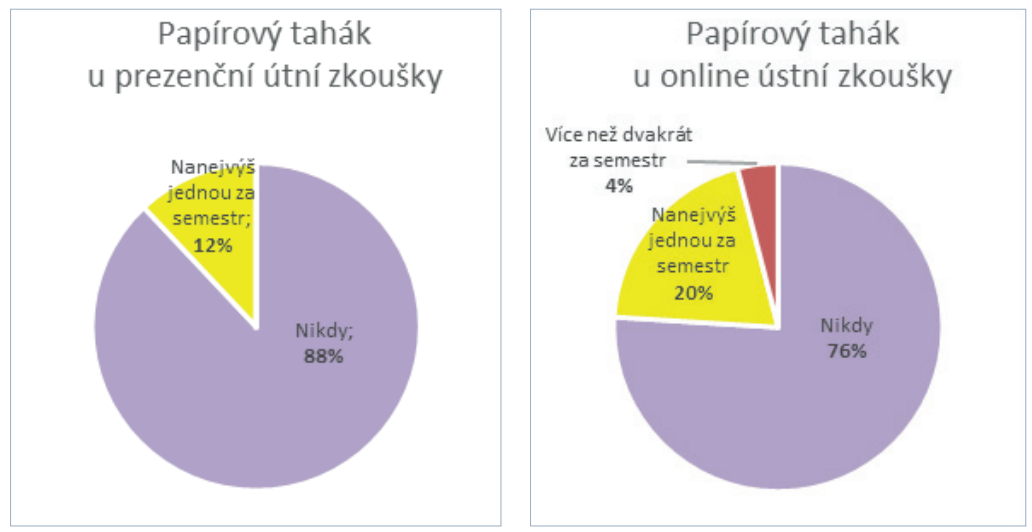

Obr. č. 6: Grafy porovnávající využívání taháku na displeji v době prezenční výuky (vlevo) a v době distanční výuky (vpravo) u studujících Učitelství pro 1. st. ZŠ na FPE ZČU. 
Otázka č. 4:

\section{Jak často jste používali u zkoušek tahák na displeji mobilu nebo počítače?}

Respondenti - studijní program Učitelství pro MŠ
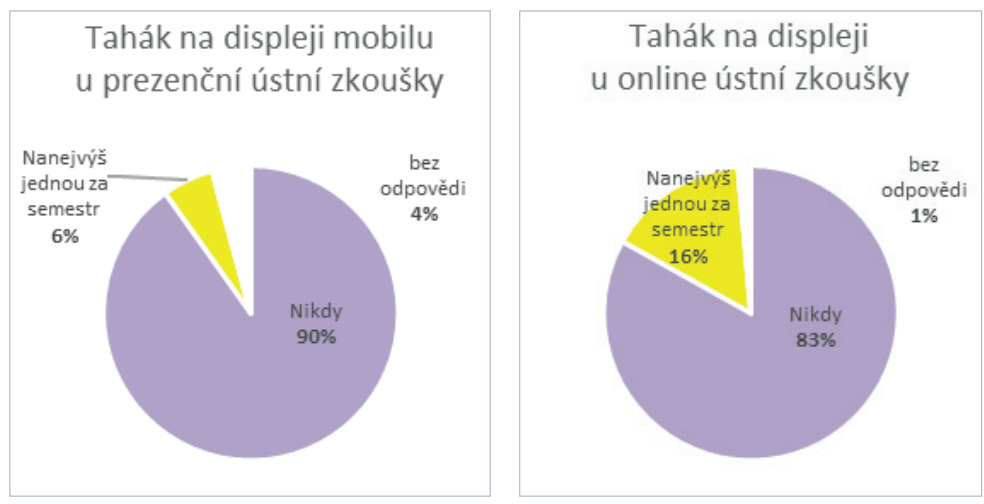

Obr. č. 7: Grafy porovnávající využivání taháků na displeji v době prezenční výuky (vlevo) a v době distanční výuky (vpravo) u studujících Učitelství pro MŠ na FPE ZČU.

Respondenti - studijní program Učitelství pro 1. stupeň ZŠ
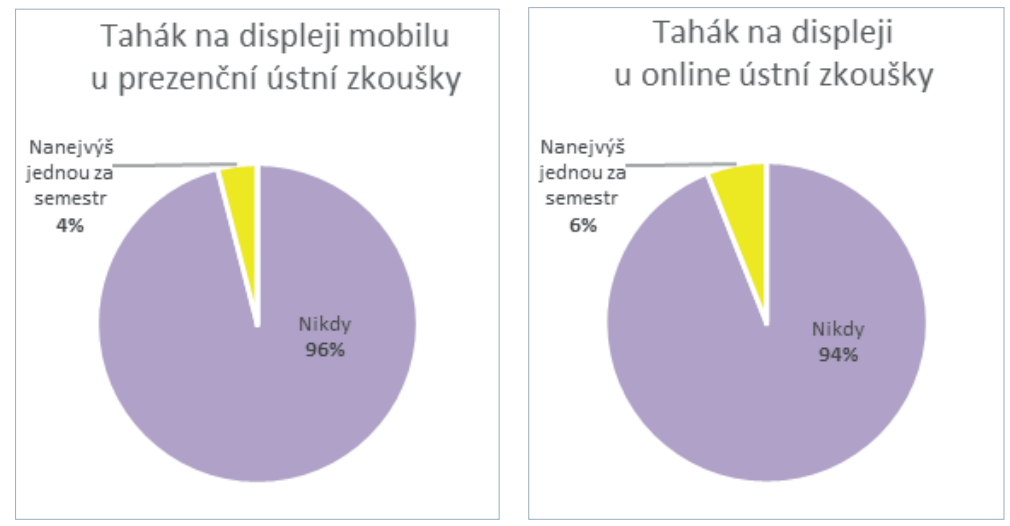

Obr. č. 8: Grafy porovnávající využivání taháku na displeji v době prezenční výuky (vlevo) a v době distanční výuky (vpravo) u studujících Učitelství pro 1.st. ZŠ na FPE ZČU. 


\section{Závěr a diskuse}

Vysoké školy sice využívají pro kontrolu písemných prací program na kontrolu plagiátorství, ale odhalit podvádění během písemného online testu je těžké, obzvláště pokud student plní test v domácím prostředí. Je několik možností, jak co nejvíce eliminovat podvádění při on-line testování, ale všechny přinášejí svoje obtíže. Je např́íklad možné, aby student před testem vyfotil svoje pracovní místo a foto poslal vyučujícímu. Tuto možnost můžeme považovat za nereálnou, nebot' vyučující má např. na plnění testu přihlášeno 100 studentů, tudíž není v jeho silách kontrolovat všechna fota, nehledě k tomu, že nemůže znát pracovní prostředí každého studenta. Vyloučit prrítomnost další osoby při psaní testu je také velmi obtížné, zrovna tak jako vyloučit umístění papírového taháku na psacím stole. Jedinou možností tak zůstává seznámení studentů s etickým kodexem akademického prostředí a s možnými postihy při jeho nedodržení. Podvádění v rámci distančního ověřování znalostí má negativní vliv na celou tzv. akademickou integritu, kterou chápeme jako „závazek a projev čestného chování v akademickém prostředi“. Síla akademické integrity je nepř́mo úměrná s frekvencí podvádění. (Miller, 2011) Tedy pokud budeme posilovat akademickou integritu v rámci studentů - členů akademické obce, přirozeně budeme potlačovat i potřebu podvádění.

Studentské podvádění je jev nežádoucí na všech vysokých školách. Řešení tohoto neetického jevu v době distanční výuky je ještě obtížnější než v době prezenční výuky. Každý pedagogický pracovník by měl mít vypracovanou svoji preventivní strategii, aby k podvádění v době distanční výuky docházelo jen minimálně.

Akademičtí pracovníci si obecně uvědomují, že při online zkoušení je snazší podvádět než při klasickém prezenčním, ale studenti tento názor paradoxně nesdílí (Reedy a kol. 2021). Výsledky našeho výzkumu ukazují, že se online forma zkoušení nepromítla na statisticky významném nárůstu podvádění. Tedy forma zkoušení (online nebo prezenční) není pro míru podvádění směrodatná, což potvrzuje zjištění Alison Reedy (2021), Laury Harris (2020) nebo Aparny Chirumamilla (2020) z Norska.

Učitelé na vysokých školách realizují různá řešení, aby podvádění zabránili či jej omezovali. Některá jsme v rámci našeho výzkumu identifikovali. Obecně můžeme říci, že různě efektivními nástroji a procesy jsou:

1. prevence hrozící represí (např disciplinární řizení),

2. aplikace technických bariér (omezení webového připojení, kamerový dohled aj.), 
3. parametry a vlastnosti testů (časový tlak na řešení, náhodné generování otázek a pořadí, efektivní design otázek aj.) (Sullivan, 2016),

4. posilování akademické integrity,

5. využití metod zkoušení zaměrených na aplikaci znalostí,

6. uplatnění prvků stimulujících konkurenční prostředí mezi studenty.

Australská studie vysokoškolského podvádění odhalila fakt, že „studenti a zaměstnanci považují nedostatek dohledu za hlavní faktor, který studentům umožňuje podvádět". (Reedy a kol., 2021). V praxi aplikujeme vždy více řešení pro omezení možnosti školního podvádění. V souvislosti s posilováním akademické integrity se v České republice formuje v rámci projektu Posilování akademické integrity studujících vysokých škol se zaměřením na rizika a př́ležitosti distančních metod vzdělávání a hodnocení odborná platforma, jejíž cílem je sdílení dobré praxe $\mathrm{v}$ rámci distanční výuky a prevence podvádění. (MUNI, 2021).

Didakticky nejcennější je koncepce ověřování znalostí s využitím metod zkoušení ověřujících spíše než samotné faktografické znalosti jejich aplikaci v praxi na úrovni dovedností a kvalifikovaného posuzování reálných skutečností (bod 5) nebo s velkou opatrností aplikované podnícení konkurenčního prostředí mezi studenty (bod 6). Konkurenční prostředí totiž obecně působí proti spolupráci studentů (Shore, Venkatachalam, 1996). Studenti nebo lépe skupiny studentů, vzájemně soupeři a jakékoliv sdílení informací nebo řešení před jeho prezentací je kontraproduktivní. Pochopitelně musí být nastaveno odpovídajícím způsobem i hodnocení. Toto je však značně sporné řešení na úkor dosahování cílů vzdělávání v oblasti rozvoje sociálních dovedností a z hlediska jeho aplikovatelnosti naráží na ještě významnější etické dilema než akceptantce studijních výsledků dosažených v rozporu se studijním a zkušebním řádem dané vzdělávací instituce. V extrémních prŕípadech vede až $\mathrm{k}$ izolaci jednotlivců a nárůstu moci vědomostních elit.

Mnohem efektivnější je navrhnout multiple-choice testy s náhodným generováním otázek (bod 3), promícháním velkého množství možných odpovědí (typicky 6 až 8) a sekvenčním postupem testem bez možnosti návratu. Má-li student na řešení testu vhodně zvolené množství času a nemůže mezi testovými otázkami pohybovat dopředu a zpět, omezí se vzájemné razení mezi studenty, nebot každý ze studujících účastnících se testu je zaměstnán řešením individuální sady otázek a nezbývá jí nebo jemu čas na pomoc ostatním. To ovšem platí pouze pro první pokusy. Při opravných (tedy druhých a třetích) pokusech již studující, kteří úspěšně absolvovali test na první pokus intenzivně radí pomocí online komunikačních 
prostředků ostatním (viz dále). Náhodné generování pořadí otázek, nemožnost se mezi otázkami volně v testu volně pohybovat i promíchání nabízených odpovědí $\mathrm{k}$ dané otázce náhodně pro každého účastníka testu tak pouze snižují množství studentů, kterým může daná osoba radit, takže jeden člověk nemůže diktovat výsledky všem najednou. Osvědčilo se např́iklad nechat studenty vybírat správná tvrzení ze sady 8 různě modifikovaných definic tím, že správně mohlo být několik $\mathrm{z}$ nich.

V uvedeném ilustrativním prríkladu testu z elektrotechniky v LMS Moodle mají studenti na posouzení správnosti sady osmi posuzovaných tvrzení 2 minuty času na každou otázku, respektive sadu tvrzení, z celkem 25 sad s celkovým časem pro jejich řešení v délce 50 minut. Výsledkem je u prvního pokusu rozprostření výsledků úspěšnosti absolvování testu (v relativním vyjádření) od $0 \%$ do cca. $80 \%$. Razení úspěšných studentů $\mathrm{v}$ druhém pokusu se následně projevuje posunem distribuce výsledků směrem $\mathrm{k}$ výrazně vyšším hodnotám, což musí reflektovat jiné nastavení hranic pro přiřazení známek v každém dalším pokusu. $\mathrm{Z}$ toho důvodu je také vhodné u prvního pokusu nastavit vysokou hranici pro zisk hodnocení „výborně“ (v ČR „1“, mezinárodně Grade „A“) velmi vysoko, tak aby i u dalších pokusů byli úspěšní studující motivování test opakovat a nebyli k dispozici pro razení ostatním.

Závěrem k zamyšlení. Morální hodnoty studentů a respekt k akademické integritě „snižují pravděpodobnost, že studenti budou podvádět, pokud bude prostředí zkoušek a hodnocení považováno za spravedlivé" (Reedy a kol., 2021).

\section{Literatura}

Chirumamilla, A., Sindre, G. \& Anh Nguyen-Duc (2020) Cheating in e-exams and paper exams: the perceptions of engineering students and teachers in Norway, Assessment \& Evaluation in Higher Education, 45:7, 940-957, DOI: 10.1080/02602938.2020.1719975

Bajtoš, J., Honzíková, J. \& Bajtoš, M. (2020). Hrozby Plagiátorstva počas dištančného štúdia v období pandémie COVID-19. ITEV, 1/2020, 82-87

Bajtoš, J \& Honzíková, J. (2019). Školské podvádzanie z pohl’adu učitelov - pilotné výskumné šetrenie. Arnica, roč. 2019, vyd. 2., 51-58

Bajtoš, J. \& Marhevková, A. (2016). Školské podvádzanie - problémový aspekt hodnotenia výkonov žiakov. Bratislava, Wolters Kluwer. $101 \mathrm{~s}$.

Bernardi, R. A., Baca, A. V., Landers, K. S. \& Witek, M. B. (2008). Methods of Cheating and Deterrents to Classroom Cheating: An International Study. Ethics \& Behavior 18(4): 373-391

Cibulková, A. (2013). Podvádění očima středoškolských učitelu․ Masarykova univerzita, Brno. 70 pp.

Cizek, G. J. (2003). Detecting and Preventing Classroom Cheating: Promoting Integrity in Assessment. Experts in Assessment. Corwin Press, Inc., CA, Thousand Oaks. 173 pp. 
Clark, K. (2008). Taking a Bite Out of Cheating, With the Help of Technology. U.S. News \& World Report.

Eisenberg, J. (2004). To Cheat or Not To Cheat: Effects of Moral Perspective and Situational Variables on Students' Attitudes. Journal of Moral Education 33(2): 163-178

Garavalia, L., Olson, E., Russel, E. \& Christensen, L. (2007). How The Students Cheat? 33-55 In Anderman, E. \& Murdosck, T. (eds) Psychology of Academic Cheating. Academic Press, Amsterdam, Boston.

Gray, P. (2013). Podvádzanie vo vede II: Škola pripravuje pôdu podvádzaniu (nielen) vo vede. Preklad: Sčigulinský, P. Sloboda učenia. 2014. [on line]. [cit 2019-04- 19]. Dostupné na: http:// www.slobodaucenia.sk/clanok/ podvadzanie-vo-vede-ii

Haines, V. J., Diekhoff, G. M., Labeff, E. E. \& Clark, R. E. (1996). College Cheating: Immaturity, Lackof Commitment, and the Neutralizing Attitude. Research in Higher Education 25(4): 342-354.

Havlová, J. (2003). Plagiátorství. In Česká terminologická databáze knihovnictví a informační vědy. Praha: Národní knihovna ČR. [onl ine]. [cit. 2020.04.07]. Dostupné na: http://aleph.nkp. $\mathrm{cz} / \mathrm{F} /$ ?func $=$ direct\&doc_number $=000014609 \&$ local_base $=\mathrm{KTD}$

Harris, L., Harrison, D., McNally, D. et al. Academic Integrity in an Online Culture: Do McCabe's Findings Hold True for Online, Adult Learners?. J Acad Ethics 18, 419-434 (2020). https://doi. org/10.1007/s10805-019-09335-3

Honzíková, J., Simbartl, P. \& Bajtoš, J. (2020). Digitální technologie jako nástroj školního podvádění na střední škole. Journal of Technology and Information Education. Roč. 20. Číslo 2. pp.102-111. DOI: $10.5507 /$ jtie.2020.015

Kumar, M. J. (2012). Honestly Speaking about Academic Dishonesty. IETE Technical Review 29: $357-358$.

Mareš, J. (2005). Tradiční a netradiční podvádění ve škole. Pedagogika 55(4): 310-335.

Miller A., Shoptaugh C. \& Wooldridge J. (2011). Reasons Not to Cheat, Academic-Integrity Responsibility, and Frequency of Cheating, The Journal of Experimental Education, 79:2, 169184, DOI: 10.1080/00220970903567830

Norman, J. \& Harris, M. W. (1981). The private life of the American teenager. Wade. California, Rawson. 311 pp.

Vrbová, J. \& Stuchlíková, I. (2012). Školní podvádění starších žáků - pilotní studie. Pedagogika 62(3): 317-331.

Simkin, M. G. \& Mcleod, A. (2010). Why Do College Students Cheat? Journal of Business Ethics 94(3): 441-453.

Shore, B., Venkatachalam, A. R. (1996). Role of national culture in the transfer of information technology, The Journal of Strategic Information Systems 5(1): 19-35. https://doi.org/10.1016/ S0963-8687(96)80021-7

Sullivan, P. D. (2016). An integrated approach to preempt cheating on asynchronous, objective, online assessments in graduatebusiness classes. Online Learn 20(3):195-209. https://doi.org/10.24059/ olj.v20i3.650

Internetové zdroje

https://www.vysokeskoly.cz/clanek/v-britanii-roste-pocet-podvodu-behem-distancni-vyuky-vladachce-zakazat-weby-pro-objednani-praci-na-zakazku

https://www.universitas.cz/ze-sveta/6552-studie-zavedeni-distancni-vyuky-a-zkouseni-vedlo-knarustu-podvadeni-online

MUNI 2021, https://www.muni.cz/en/research/projects/59527 